\title{
Ability of managers for crisis management in small enterprises: study in Bosnia and Herzegovina
}

\author{
Vlado Medaković ${ }^{1 *}$, Slaviša Moljević ${ }^{2}$, Ranka Gojković $^{3}$, Srđan Vasković $^{4}$ \\ ${ }^{1}$ University of East Sarajevo, vlado.medakovic@gmail.com, Bosnia and Herzegovina \\ ${ }^{2}$ University of East Sarajevo, slavisavgd@gmail.com, Bosnia and Herzegovina \\ ${ }^{3}$ University of East Sarajevo, rankagojkovic@gmail.com, Bosnia and Herzegovina \\ ${ }^{4}$ University of East Sarajevo, srdjan_vaskovic@yahoo.com, Bosnia and Herzegovina
}

\begin{abstract}
Since the enterprise have been existing, crisis of enterprise is well-known. Researches in area of possible appearance crisis in small and medium size enterprises, and sciense enterprise management which is crisis, have large significance when we talk about survival those enterprises, apropos possible prevention their bancrot. We can see that theory is mostly dedicated to enterprises repairing. The early symptom in sight of crisis and prevention latent crisis of enterprise are pointed up. Crisis management and analysis of strategy for turn out from the crisis, as we can see in this is paper, expand views and enable giving certain recomendations for appliance in practice.
\end{abstract}

\section{Introduction}

The bankruptcy of small and medium enterprises all over the world, ranging between $50 \%$ and $60 \%$ in the first year of operation (start-up), Medaković [1], Jojić and Božić [2], David [3].

The causes of bankruptcy are different, not the existence of the mission, vision and strategy to the poor product range, marketing, and poor organizational structure. The main reason for bankruptcy, the company's poor management, ie. management incompetence and his inability to recognize the threats facing the company in the early and transitional stage of its existence.

In theory and practice, we often encounter the dilemma of demarcation functions of entrepreneurs and managers. Of course there are differences, however, this distinction depends on the quantity of the enterprise in various companies, or by way of corporate management. In any case, it is impossible to imagine the company's operations outside of the chain (Ownrship - Market Entrepreneurship - Management), Medaković [1], Ford [4].

Max Weber advocated the view that bureaucratic organization is an ideal type of organization. He, however, was aware of the possibility of abuse of power in the modern organization. Misuse of power may be internal, when participants are exploited or neglected or are not otherwise involved in the organization of public goods and services. Pathology of the modern business organization is struggling with one another and with the problem. As it seems these problems are based on the abuse of power.

Problems that affect the individual participante include alienation, inequality or ritualism. Alienation can be defined as a subjective feeling of weakness or selfalienation or objectively as a condition under which workers are losing control over the products of their labor or the value they have created.

Since the time of Adam Smith onwards, the researchers examined the consequences of organizational involvement, and in particular, the employment of individual participants - the ways and forms of employment in the organization and management efficiency.

In the Republic of Srpska and Bosnia, Serbia, Croatia segregation in employment is made on the basis of belonging to a political party or a privileged group. At the organizational level segregation of jobs in origin, or membership in a group is not just alienation but ill highly criminal society and its institutions.

All organizations providing benefits to external audiences - consumers, customers, citizens - as a condition for its continued existence. Use of this audience requirements vary according to the nature of the organization, they may include direct payments for goods or services received, indirect support in the form of taxes and normative support in the form of goodwill and legitimacy.

\footnotetext{
*Corresponding author: vlado.medakovic@gmail.com
} 
The response to the needs of external audiences is a concern for all types of organizations, especially those that are external users and/or people connected as primary users. Since the private sector is expected to respond to economic signals - for example, the decline in business because customers are looking for better quality and lower prices. However, the decentralization of ownership and control, and encouraging managers still do not answer the wishes of customers.

\section{The crisis of the life cycle company}

Stage of development of small business is the most important period in the life cycle of the company, and this is the period in which the most common crisis companies, even in $60 \%$ of cases, Jojić and Božić [2], Senić [5].

At this level of growth, the company may either continue to grow and begin to use the profits to block roads or restricting its growth. Some companies survive only during development. Usually, but not always, the development phase begins in the second year of business and takes about two years.

The following scenario, shown in Fig. 1. helps to understand the life cycle of a competitive firm and a sense of each stage of the cycle.

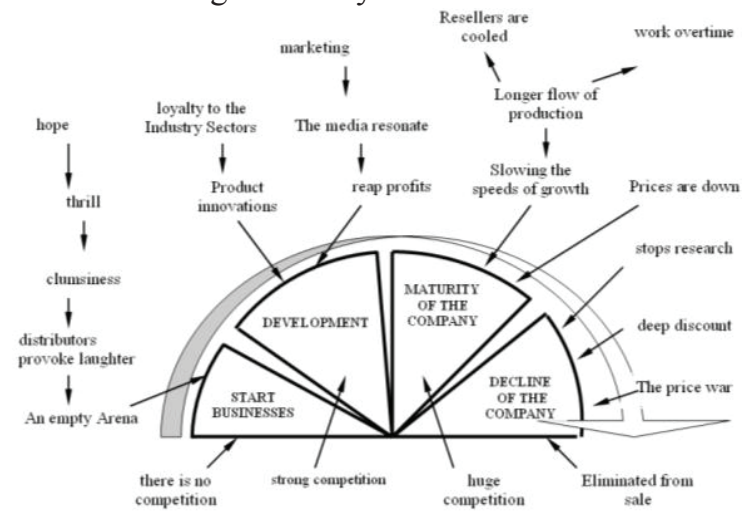

Fig. 1. Crisis scenario life cycle of the company, Medaković [1]

In the embryonic stage, the market is exciting, euphoric naive collision with the truth, that causes laughter, a high failure rate and a lot of negotiation. Price is experimental. The sales volume is low, because the market is very small and the production and marketing costs are high. Dealers are difficult to find, and the sellers are looking for a huge margin. Profit is a risky and speculative. Shrewd entrepreneur, however, can be approximated assess the "core markets". The competition has not yet emerged.

Growth phase was identified as product innovation, strong acceptance of products, beginning loyalty industry, the promotion that "bursting" through the media, the price is indicative. Product innovation continues. Distribution becomes all important. Resellers who were "laughing" during the initial phase now loudly complaining of product distribution. Strong competition, excited scent of money entering the market arena as find the group of target customers superior profits shows signs of growth.

Stage of maturity has been marked as the peak number of customers and generating zero modification. The design is focused on production differentiation rather than product promotion. Competitors are now blinded, they give impulse even when the speed slows shelves. Production is extended, so that firms can exploit the full advantage of capital equipment and management experience. Resellers anticipate rapid collapse, the growing cold products. Investing in advertising is growing compared to the competition. Prices are falling slowly. Any competitor who enters the market, it is now or dumb or over-confident, or both. Once the market becomes hot, it pervades the breath of depression. Decay phase is marked as extreme depression in the market. Competition is becoming desperate. Promotion disappears. Price war continues. Relentless fight for what is left of the core market. Reseller is impossible to find "they disappeared."

The crisis the company largely depends on the vested interests and political interaction between, the influence of organizational and adhokratije anarchy and chaos, and ultimately self-organization.

The politicians are competing with each other in order to obtain a favorable status as an entrepreneur dynamic forces in the private sector, which searches for profitable projects by offering goods and services in a competitive market depends on supply and demand. Today we are seeing that political power has an increasing impact on small businesses and the entrepreneurs. With the support of policy and interest groups are trying to provide the best possible position and as quickly become favorites in their industry, and to provide power.

\section{Empirical studies of crisis in the small and medium enterprises}

Complete information about the characteristics of a set gives only statistical list. Since the census requires a lot of time to create a large cost, it is replaced by the sample, which is part of the basic set and chosen without bias, ie. objective and whose purpose is to provide a reasonably accurate information about the characteristics of the entire sample set from which it originates.

To be credible conclusions about the characteristics of the basic set, we make based on the sample, the sample should be representative, that should be their composition similar to a basic set.

The study was conducted in the Republic of Srpska, closer location from which the sample is appropriate Podrinje region or territory following municipalities of Bratunac, Srebrenica, Zvornik, Višegrad and Foča. Investigations were carried out in the business at this location, whose random sample I came up. The sample companies are: companies face - singular and partner companies, a capital company: joint stock companies and cooperatives. 
Research on this topic, not only in the Podrinje region, but also in the Republic of Srpska and Bosnia and Herzegovina are very rare or not implemented at all, so it is difficult from the standpoint of patients eligible and unpopular, mainly due to fear of public presentation of certain data.

The sample is formed by 40 enterprises, which by their nature, organization, number of employees, total annual income, be representative and fully meet the requirements set out in the order of this paper.

\section{Results and discussion}

The survey covered 34 enterprises whose legal form of organization singular - a partnership firm, then we have 4 companies that are organized as a corporation and two enterprises that are organized as a agricultural cooperatives.

The number of managers is 9 women and 31 men. In order guaranteed discretion of managers, their age will not be shown here, and the age of the company is classified into several categories, as shown in Fig. 2.

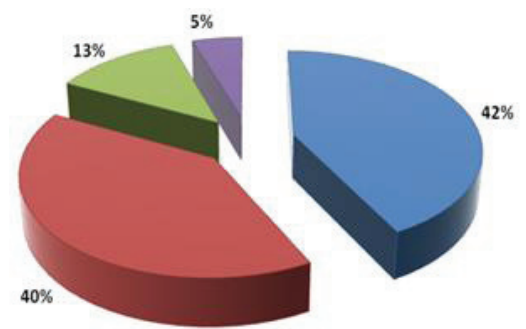

口under 5 years

From 5 to 10 years

aFrom 10 to 15 years

axceeding 15 years

Fig. 2. The age of enterprises, Medaković [1]

It is obvious that small and medium-sized enterprises in the region of Podrinje fairly young, because the representation of companies under the age of 5 years $42 \%$. Therefore subject to all the influences, both external and internal factors of instability.

Activities of companies that are the subject of the research are presented in Fig. 3.

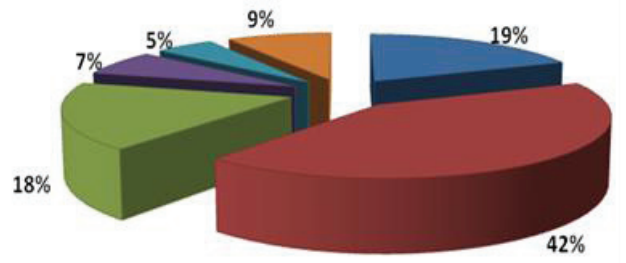

『products enterprises

Ilcommerce

匹services

Dagriculture

『building construction

『manufacturing

Fig. 3. Activities of the company represented, Medaković [1]
Generally given the third graph, conclusions can be drawn that a large number of companies engaged in commerce $(42 \%)$ and that there is market saturation and competition is getting stronger, and those who want to survive have to adapt to that situation or reorient to a different activity. In the future business of the company in the field of services, or the provision of services in all areas of social, technical, educational, health, and so on., Tend to increase and the majority of small businesses will be exactly the service of character.

The survey covered enterprises employing different number of workers, as shown in Fig. 4, where one can see four intervals of number of employees and the percentage of workers employed in small and mediumsized enterprises.

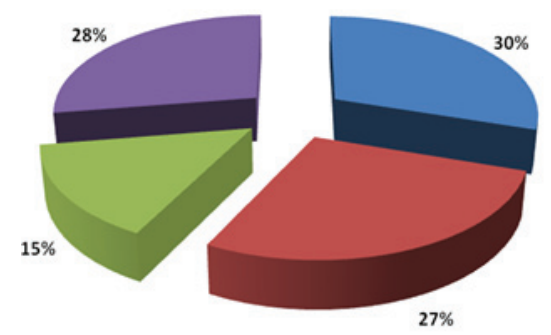
= up to 10 persons employed
च 10 to 20 employees
= 20 to 30 employees
more than 30 employees

Fig. 4. Number of employees in small and medium-sized enterprises, Medaković [1]

Based on Figure 4 it can be concluded that a substantial number of small companies, $30 \%$ employ less than ten workers, indicating that a significant number of micro enterprises participating in the small and mediumsized enterprises.

As far as managerial experience, analysis of the survey can be concluded that included managers from small and managers with extensive experience. In Fig. 5. management experience has shown that is divided into three categories, time intervals Conducting managers.

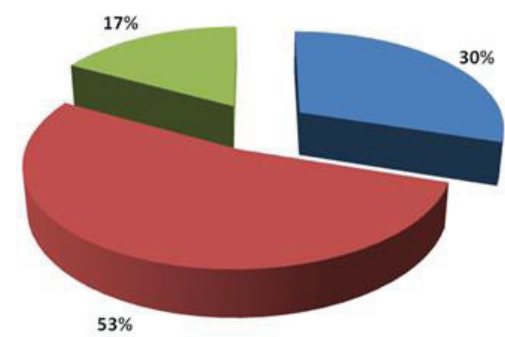

wunder 5 years

uFrom 5 to 10 years

=exceeding 15 years

Fig. 5. Years of managerial experience, Medaković [1]

The percentage of $30 \%$ of managers with experience

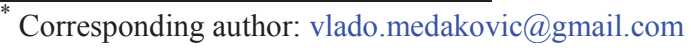


of 5 years indicates that just recently there was a rapid development of the private sector and the emergence of small and medium enterprises of different industries.

The third part of the survey effectiveness and creativity has a psychological test that is related to the effectiveness and creativity of managers.

This test demonstrates the extent to which managers have the ability to manage the crisis and which companies are the characteristics that are dominant in their personalities.

The analysis is presented Fig. 6 which displays the points depending on years of managerial experience, where we also had a manager is that the three groups. Manager with experience of 5 years, then a group of managers with experience of 5 to 15 years and a group of managers with over 15 years experience.

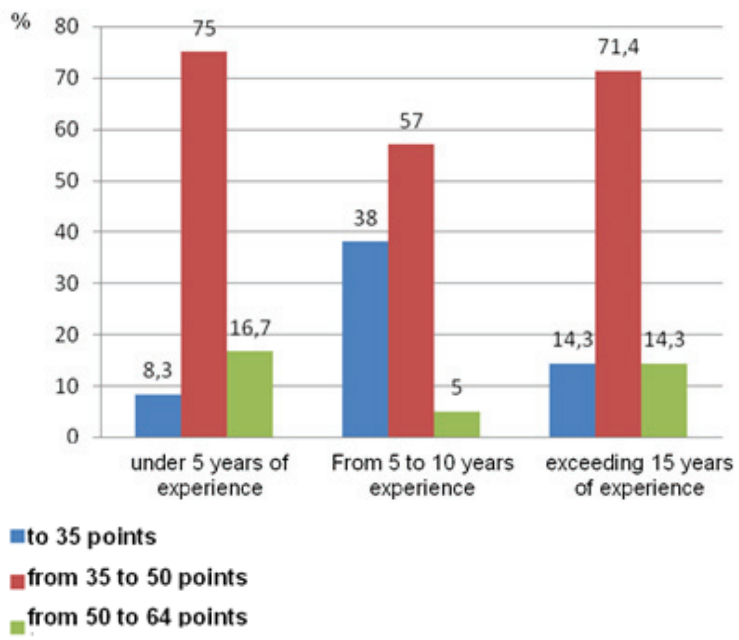

Fig. 6. Procentuala ability to manage a crisis managers in small and medium-sized enterprises, Medaković [1]

With Figure 5 that at first glance conclude that years of managerial experience are crucial when it comes to crisis management in small and medium-sized enterprises.

We see that in all three groups, which were formed on the basis of years of managerial experience, the number of points in the interval from 36 to 50 represented a large percentage, it gives us hope that the managers of small and medium-sized companies willing to venture enterprise management which threatens crisis or is already in crisis. Managers with experience of 5 to 15 years are less involved in monitoring and comprehensive changes that were "put to sleep" in their work, and would for that reason you should pay more attention to innovation in leading companies.

\section{Conclusion}

We are aware that the environment in which companies operate is becoming more dynamic. Today we live in a time of faster, complex and unpredictable changes, all of which significantly affect the operations and management services. Response to rapid changes in the environment have become more discontinuous character, which asks managers of companies to achieve major shifts in the short term.

Empirical studies have been conducted on the territory of the Republic of Serbian shown that small and medium-sized enterprises in a number are in crisis and that the necessary use of such knowledge and skills of crisis management.

Corporate Responsibility (owners of small and medium enterprises) as well as manager of the Republic of Serbian is at a high level as well as the temptation of finding the right path out of the crisis in which we find ourselves. If we lose way and start to be afraid of new technology, new types of managers, voice of other developed countries and cultures, then inevitably remain in the vicious circle of crisis. Managers who are able to bring to the organization a passion for change and a competitive spirit can count on the future.

\section{References}

[1] V. Medakovic, Development of a model for crisis management in small and medium-sized enterprises (original „Razvoj modela za upravljanje krizom u malim i srednjim preduzecima"), magistarski rad, FTN Novi Sad, 2008.

[2] R. Jojić, R. Božić, Entrepreneurship for new century (original "Preduzetništvo za novi vijek"), Srpsko Sarajevo - Priština, 1998.

[3] R. F. David, "Strategic management", Fifth Edition, Prentice - Hall International, Inc. Englewood Cliff, New Yersey, 1995.

[4] J. D. Ford, "The Management of Organizational Crisis", Business Horizont, May/June 1981.

[5] R. Senić, Crisis management (original "Krizni menadžment”), Beograd, 1996.

\footnotetext{
*Corresponding author: vlado.medakovic@gmail.com
} 